\title{
The Role of Pakistan in the Organization of Islamic Conference*
}

\author{
Sulayman S. Nyang**
}

The rise of Western naval power in the world was the consequence of the earlier Iberian discovery of peoples, societies and cultures beyond the seas known to the Europeans of the early fifteenth century. It was indeed these forays and adventures that gradually led to the imposition of Western colonial and imperial rule over what were previously independent societies and cultures in Asia and Africa. The Muslim societies, along with Buddhist, Hindu, Eastern Christian and traditional African peoples, were all brought under one European imperial roof, and their societies exposed to the transforming powers of Western industrial might.

It was of course this rise of the West and the declire of the East that led to the parcelling out of Muslim lands and to the alteration in the direction and flow of cultural and intellectual exchanges between the Muslims of the Indian subcontinent and their brethren elsewhere in Darul Islam. With such a division of the Muslim lands, each Muslim people living under a given colonial power tried to maintain its Islamic identity against whatever odds there were in that colonial system. Pakistanis were part of this global phenomenon and the creation of their country in 1947 dramatized the Muslim feeling of loss of unity and the urgent need to recover the universal feeling of Islamic solidarity which colonial rule seemingly derailed from the tracks of human history.

In this paper I intend to examine and analyze the role of Pakistan in the Organization of Islamic Conference (OIC). Working on the understanding that Pakistan at the time of the formation of the OIC in 1969 , was the most populous Islamic state in the world and that its very creation was occasioned by the Islamic sentiments of the Muslim

\footnotetext{
*A paper presented at the 12th Annual Conference on South Asia at the University of Wisconsin, Madison Campus 1983. We give credit to the Journal of South Asian and Middle Eastern Studies, Vol. 7, No. 3, Spring 1984.

${ }^{* *}$ Sulayman S. Nyang, Ph.D., Editor-in-Chief of AJIS, is an Associate Professor of Government and Public Administration at the Center for African Studies, Howard University, Washington, D.C.
} 
minority in colonial British India, this paper studies how Pakistan operates with the newly created Islamic commonwealth of states. It also focuses on the contributions that Pakistan makes to the welfare of the Muslim World and on the benefits she derives from her association with the OIC. To document further these processes of political, cultural and economic unity the paper looks at the record of Pakistan's trade and commerce with the Muslim countries. While pursuing an historical and analytical approach to the understanding of Pakistan's behavior in the Muslim world, efforts will also be made to place the evidence in the framework of Pakistan's global foreign policy.

\section{A. Pakistan Foreign Policy and Muslim Solidarity, 1947-1969}

The foreign policy of Pakistan has been the subject of discussion for scholars, diplomats, politicians and journalists writing on South Asian affairs and the Islamic World. It is generally agreed in the literature that Pakistan's foreign policy has been determined from the very beginning by her geography, her history, her cultural ties to the Muslim world, and her determination to survive in the politically charged diplomatic universe of the three super powers. The geography of the old Pakistan of 1947 made her the inheritor of two important parts of the British Raj, namely West Pakistan and East Pakistan (now called Bangladesh). But both parts of the old Pakistan were truncated sections of the British Raj in the Indian subcontinent and there was no way to demarcate the borders of India and Pakistan without leaving Hindus and Muslims on either side of the border. It was indeed this fragmentation of the Indian subcontinent that constituted and still constitutes a fundamental problem in Pakistan-Indian relations. Yet, in stating the sources and origins of Pakistan's foreign policy problems with her Indian neighbor, one must hasten to add that what was imperially convenient to British colonizers was inconvenient and suffocating to the Muslim minority in India. Though many middle class Muslims in British India were beginning to feel comfortable towards the end of the British Empire, there was still the feeling of insecurity about the future in postcolonial India. In my view, the creation of Pakistan was the result of three factors which the Muslim leadership could not ignore when the prospects of living under Hindu majority rule became crystal clear to them. The first factor was the fear that Muslim identity in Hindu-dominated India was most likely to be threatened by the secular democracy which the British left as legacy to the Congress leadership. This was so because, in a religiously fragmented society such as India, secular democracy could paradoxically be the weapon used by the Hindu majority to keep the society Hindu and Secular. Both prospects are unacceptable to Muslims unwilling to live under Hindu rule. The second factor was the overwhelming statistical evidence of Muslim economic deprivation in the last days of British India. The third factor was psycho- 
political in the sense that, whereas the Muslims could reluctantly accept colonial domination from British Christians because they are considered religious cousins and people of the book, their attitude to the Hindu was fundamentally negative. Added to this was the stark reality that in postcolonial India, Muslims would certainly not lord it over the Hindus as the Muslim conquerors of earlier times did.

It is of course against this background that one can understand the Pakistan Movement and the ironies and paradoxes of both modern Pakistani and modern Indian history. The idea of Pakistan, in my view, took a concrete form in the last two decades of British India because of the three above mentioned factors. Unwilling to get drowned in the sea of Hindu culture and strongly convinced that the odds for the creation of a viable Muslim State are better under British midwifery than in postcolonial India, many Muslim leaders decided to settle for Pakistan. This decision to part with Hindus was destined to affect Pakistan's relations with independent India and Pakistan foreign policy in general.

Writing on the motivations behind the Pakistan Movement, a Pakistani writer argues that when it became glaring clear to India's Muslims that the Congress was ready to succeed the British Raj, they began to assert their separate and distinct identity. As he puts it:

Muslim thinking crossed the rubicon and veered round the view that Muslim India's salvation lay in a drastic departure from the beaten track and the establishment of a separate sovereign state comprising areas of Muslim majority. The idea of such a state had been mooted by several thinkers in the past such as Jamaluddin Afghani, Khair Brothers, Abdul Qadir Bilgami, Sardar Gul Khan and Chaudri Rahmat Ali. In 1930 Allama Iqbal put it forward as a political proposition in his address to the All-India Muslim League at Allahabad in $1930 .{ }^{1}$

This statement of Jamil-ud-din Ahmad provides a clue to the problem, and what can be added here is that since the emergence of Pakistan her leaders have seen her as a Muslim oasis in the cultural desert of South Asia and those brethren who are still living in India deserve Pakistani attention and support. Up until the 1960 s and 1970 s, Pakistan's foreign policy placed great emphasis on the Kashmir question. Concern was also expressed for the safety and well-being of Indian Muslims in other areas of India.

It was indeed these Pakistani concerns for those Muslims in Hindu-dominated India and her strong and uncompromising stance regarding the Kashmir question that led to two wars with India. Pakistan's foreign policy objectives included not only the security of

'Jamil-ud-Din Ahmad, "Motivations Behind The Pakistan Movement," Contemporary Affairs, Vol. 2, No. 6. (Summer, 1970), p. 128 
Muslim rule in Pakistan but also the expression of solidarity with Muslims far and near. In the opinion of one Pakistani writer, if Kashmir was for India "a symbol of non-acceptance of the two-nation theory; a consolation prize for the 'disaster' of Partition," for Pakistan, "Kashmir became a symbol of the unfinished business of the pre-independence struggle against the Hindu Congress". ${ }^{2}$

Because of the geopolitical and strategic realities, Pakistani leaders began to grope for diplomatic certainties in a world environment that was becoming increasingly secular. Committed to an Islamic State but cognizant of the peculiarity of Pakistan in this secularistic world, they began to reach out for friends and allies. Under Jinnah and Liaquat Khan Pakistan foreign policy was rhetorically neutral but sentimentally pro-Western. This was evidently due to three factors which are discernible through a careful re-reading of their statements. First of all, it should be borne in mind that the ruling elite in Pakistan were basically British educated and many of them had cultural affinities with AngloSaxon culture. Though there were misgivings and disagreements with Anglo-American societies, between them and the Soviets, the Pakistani choice was self-evident. Related to this is the second point which argues that, just as Muslims were less reluctant to be dominated by Christian colonizers than by Hindus under the British Raj, one can also argue that between a communist client and an American client, the Pakistani leaders apparently were more willing to choose the latter. The third factor which in my view accounted for the foreign policy of Pakistan in the first six yeras of independence, was the modernist attitude of the leadership. Even though most of the people in Pakistan wanted a homeland for the Muslims of the Indian subcontinent, the British presence and the inculcation of Western education and secular values had created a significant class of people in the country who wished to follow the path of rapid economic and industrial development without abandoning their commitment to Islam.

Towards the end of British colonial rule and during the early period of Pakistan's independence some Pakistanis were suggesting the creation of "a League of Middle Eastern States and Pakistan." This was a call for the creation of a Middle Eastern Union, which embraces all the Muslim States in South and West Asia. The forces opposed to such a union were the Hashemite dream of greater Syria, Afghanistan's claim over certain territories in Pakistan, Iran-Afghanistan dispute over the irrigation water in Beistan, and the Turkish-Syrian dispute over Alexandretta. ${ }^{3}$ This idea of uniting the Muslims of South Asia with their brethren through

"Kalim Siddiqui. "Pakistan's External Environment," Asiun Rerieu Vol. 2. No. 2 (January, 1969), p. 118-119.

${ }^{3}$ M. Ahmad, Pakistan and The Middle East (Karachi, Pakistan: Kitabi Markaz, 1948), p. 212. 
some form of intergovernmental union was also received with much reservations by the leaders of Turkey.

Writing on the early relations of Pakistan and the Middle Eastern countries, a Pakistani author tells us that Turkey was not enthusiastic about the idea of an Islamic Pakistan. This was of course in keeping with the Kemalist legacy of secularistic modernization. In fact, our author, citing a work by Toynbee and Kirkwood, quoted a Turkish official as saying:

The West need no longer fear, and Muslim people need no longer hope, that we shall wish to champion the cause of every Muslim people that is struggling to throw off the yoke of Western domination. As far as that yoke weighed upon us, we have broken it single-handed. Let other Islamic peoples prove their worth by fighting their own battles as we have fought ours. We shall look on sympathetically, but we shall be slow to interfere. ${ }^{4}$

Whether the above statement was an exaggerated view from a single Turkish official or not, the fact remains that during this period nationalism was primary in Turkish life and society. After having expended so much in the field of secular nationalism, the Turks were quite reluctant to allow the traditionalist Islamic forces to be once again at the forefront of national life. The opposite was the case in Pakistan, where the very existence of the country and the leadership rested and still rests in the belief that Islam is the cementing factor for all the diverse ethnic and linguistic communities. To put it another way, one can say that, whereas the successors of Ataturk saw Turkish nationalism as a forest with trees of the same kind sharing the same ecological space, the Muslim Pakistanis saw their country as a vast oasis where each and everyone is united in the belief that it is better to live together here than to disappear in the sweltering heat of the adjacent Hindu desert.

Given these two different situations and contrasting attitudes towards Islamic unity, one can argue that early Pakistani leaders such as Jinnah were sensitive to Turkish and other nationalist sentiments at the time and for this and other related reasons, they tried to dissociate the idea of Pan Islamism from the reality of Pakistan. Jinnah's unequivocal declaration in May, 1946, in an interview with Mr. Donald Edwards, $\mathrm{BBC}$ correspondent, is evidence for those examining early Pakistani efforts at Islamic unity and institution-building. To allay the fears of Muslim brethren elsewhere in Darul Islam, the evidence seems to suggest, Mr. Jinnah contended that Pan Islamism was being used as a bogey to drive a wedge between Pakistan and the Muslim states. ${ }^{5}$

${ }^{4}$ Ibid., p. 297.

${ }^{5}$ Quoted by M. Ahmad, op. cit., p. 208. 
To counter this negative image and to build bridges between Pakistan and the neighboring countries, the Pakistani leadership decided to seek out new friends. This early policy of Pakistan which offered the hand of friendship to all, was pursued simultaneously with a Pan-Islamic call for unity. During this period Pakistani leaders organized conferences and exchanged visits with other Muslm leaders in the Middle East and in Southeast Asia. In fact, in the first four years of her existence, Pakistan organized at least two important Islamic Conferences. The first was the International Islamic Economic Conference held in Karachi in November, 1949. This conference attracted 18 Muslim countries. In February, 1951 Motamar-i-Alam-e-Islami(International Muslim World Organization) held its session in Karachi and was attended by over 55 Muslim countries and communities. ${ }^{6}$ An international Conference of Muslim Youths also took place in Karachi years later. ${ }^{7}$

In 1954 the Prime Minister Mohammed Ali visited Saudi Arabia during the Hajj season and a very important meeting between himself and other Muslim leaders took place. During this meeting the idea of an Islamic organization for all Muslim states was mooted out. Reporting on this meeting with leaders of Saudi Arabia and Egypt, the Prime Minister told the Pakistani nation:

I was very greatly impressed by the desire so clearly manifest in both King Saud and the Egyptian Prime Minister that all Muslim countries should come still closer and work together." 8

This idea was destined to die a quick death even though Nasser of Egypt had given it his blessings and delegated Anwar Sadat to represent Egypt. In fact, Sadat's credentials as the pointman for the Free officers during their delicate negotiations with the Muslim Brotherhood (alIkhwan al-Muslimin) in the days before the 1952 coup d'etat made him Nasser's choice to head the skeletal secretariat which the Muslim leaders wanted to set up.

This Pakistani policy of Pan Islamic solidarity failed to crystalize because of a number of reasons. First of all, by 1954 the Egyptian revolutionaries led by Nasser were beginning to broadcast loudly their commitments to, and slogans for Pan-Arabism. While Pakistani leaders were courting the Muslims in West Asia and beyond, the cold war in the world was beginning to get more and more fierce. The Korean war had heightened American apprehensions of communist intentions in Asia,

${ }^{6}$ Rafique Akhtar, edited, Yearbook for 1974 (Karachi, Hyderabad and Lahore, Pakistan: East and West Publishing Co., 1974), p. 122.

${ }^{7}$ See Pakistan Affairs, Vol. VIII, No. 1 (August 27, 1954), p. 1.

${ }^{8}$ According to Pakistan Affairs, Vol. 8, No. 9, (Jan. 14, 1955) p. 1, there were 2,000 Muslim youth leaders from 33 countries. They concluded their 6-day conference successfully and received letters of congratulation from President Sukarno of Indonesia, Prime Minister, Nasser of Egypt and King Idris of Libya. 
and under the leadership of Dulles new allies were being sought. Pakistan was one of these allies to be wooed and won over to the cause of anti-communism.

Why did Pakistan abandon her drive for Islamic solidarity and unity and ran into the American ideological embrace? Well, opinions differ, but there are areas of consensus among analysts. Some have suggested that domestic troubles led the leadership to exaggerate the threat from India and so went out to see security from abroad. ${ }^{9}$ According to Ambassador Ispahani, Pakistan's close involvement with America began in 1953, when "economic depression after the Korean war, began to appear on the horizon." He adds that worsening agricultural conditions which led to a severe drought "began to be felt in the time of Prime Minister Mohammad Ali Bogra, (who) having been in the United States, and being much impressed by the American economy, wealth and way of life, .... turned to the Americans for help." (p. 14).

It was indeed the politics of the belly as well as the politics of insecurity that drove the Pakistani leaders into the American embrace. Yet, though in retrospect one can argue that the United States of America became one of Pakistan's auxiliary breadbaskets, especially in time of need, the Pakistani understanding of the relationship as a security boost from the Americans was destined to be proven incorrect. Ispahani also attributed Pakistan's tilt towards the U.S. and Britain to the deflecting actions of sickly Governor-General Ghulam Mohammed and to his successor, whose pro-American and British sentiments completed the process of surrender to the dictates of United States and Britain". (p. 16). Others attribute the change to Pakistan's inexperienced diplomacy in the Muslim world, to the strong feelings of nationalism among West Asian Muslim States, to India's success in projecting a strong image of anticolonialism, and to the fact that many Muslim states were still colonies. ${ }^{10}$ Yet some others have claimed that the Pakistani leadership embraced the West and especially the Americans because, following the assassination of Prime Minister Liaquat Ali Khan in 1951, the group that came to power saw it as an opportunity to "secure outside economic and military aid, strengthen themselves vis-a-vis India, and compensate for rebuffs in their overtures to fellow-Muslims of the Middle East...."11

Regardless of what one may say about the first generation of Pakistani leaders the fact remains that during the first six years of independence,

"See his "The Ire of Pakistan", Asian Review, Vol. 1, No. 1 (Nov. 1968), 'see also Kalim Siddiqui's reply to Ambassador Ispahani's article in Asian Review, Vol. 1, No. 2, (Jan. 1968) and K. Sarwar Hassan, Pakistan and the United Nations (N.Y.: Manhattan Publishing Co., 1960), p. 59.

${ }^{10}$ See Ahmad Ali Khan, "Pakistan and the World. Twenty Years of External Relations" Pakistan Quarterly, Vol. 15, No. 1, 1967.

${ }^{1}$ See Norman Dunbar Palmar, South Asia and United States Policy (Boston, Massachusetts: Houghton Mifflin Co., 1966), p. 29. 
the pressure put on these leaders was too much. Though men like Jinnah were strong enough diplomatically and politically to conduct negotiations with India without in any way appearing as "traitors" and "sellouts", those who came a few years later were neither very secure at home nor prominent enough to count for much in the region itself. This case of double vulnerability must have led them to see the points of convergence between their own interests as insecure rulers and those of the American policymakers bent on building a wall of resistance against the communist menace. It was in this context that Ivar Spector reminded us that America's desire to contain the communist menace was occasioned by the alliance between the Soviet Union and Communist China, signed in Moscow on February 14, 1950. This turn of events in Asia upset the balance of power in the postwar world, both in Europe and Asia, and it became very clear that the further expansion of the MoscowPeking orbit in the direction of Southeast Asia threatened to outflank the Near and Middle East, and ultimately Europe.

According to Spector, for the first ten years after World War II and inspite of her military treaty with Japan and defensive pacts with Australia, New Zealand and the Philippines, American policy left the Orient in the hands of West European powers. Spector argues that during this same period, the Soviets subordinated European to Asian policy and that the Eisenhower administration made the American Asia-conscious. With China lost, India neutral, and Indo-China partitioned, the decision to create an effective system of Asiatic alliances to counter-balance the eight hundred million population of the SinoSoviet axis became evident. To make American alliances in Asia really effective, they had to be bolstered by large reserves of Asiatic power. ${ }^{12}$

In Spector's view, the American government soon realized that the only

effective means of accomplishing this end was the extension of its system of alliances to include the countries of the Muslim World. The leading Muslim nations are strategically located along the soft under belly of the U.S.S.R. in Asia and they have the manpower to enable the West to balance, if not to outnumber, the thickly populated countries of the Moscow-Peking orbit. Since some Muslim people are still inordinately distrustful of the Western powers, it has been the task of American diplomacy to convince them that the United States does not approach them as Masters. . . . ${ }^{13}$

It was indeed this convergence of interest between the United States

${ }^{12}$ Ivar Spector, The Soviet Union and the Muslim World (Seattle, Washington Press, 1959), p. 208.

${ }^{13}$ Ibid., pp. 208-209. 
and some of the predominantly Muslim States in South Asia and West Asia that set the ball of anti-communist alliance rolling in the geopolitical space between the Mediterranean Sea and the Indian Ocean. Reviewing twenty years of Pakistan's foreign policy, a Pakistani editor of a major publication identified three phases in the country's foreign policy. The first was the period of early independence when the country had a proWestern tendency without necessarily consummating any definite political marriage with a Western power. The second was the period when the Pakistanis became "the most allied of the allies of the United States and began to receive economic and military aid from the U.S. and joined Western-sponsored military pacts in the hope that adherence to them will strengthen its security and its capacity to resist aggression."14

In retrospect, we can now argue that Pakistan's earlier efforts at promoting Islamic unity failed because both the environment of world politics and the nationalist style of diplomacy copied from the European powers discouraged religious elements from being at center stage in international affairs. ${ }^{15}$ Added to the above mentioned point was the nature and dynamics of domestic politics in Pakistan. The fading away of the old guard of the Muslim League and the rise to prominence of hitherto unknown people created the domestic and international conditions for the local elite to hitch what appears to most Pakistanis and to many outsiders as an Islamic wagon to the American Star of anticommunism. This decision was to be regretted by Pakistani leaders in the late 1960s when it became very apparent that Pakistan's Western allies were not willing to help her deal with regional aggression from India. Rather they wanted her support only to deter the communist menace. According to Foreign Minsiter Sharifud-Din Pirzada, "our membership of Western alliances had isolated us from the mainstream of world politics and the Afro-Asian world and had earned for us the displeasure and animosity; in varying degrees of the Soviet Union and China." ${ }^{16} \mathrm{He}$ adds that the train of events in South Asia has shown that Pakistan's national interest was of secondary importance in the global calculations of Western Allies. ${ }^{17}$ To these views of the former Foreign

\footnotetext{
${ }^{14}$ Ahmad Ali Khan, "Pakistan and the World. Twenty Years of External Relations". Pakistan Quarterly. Vol. 15, No. 1, 1967, p. 51.

${ }^{15}$ This has been most evident in Pakistan/Afghan diplomacy. Since independence the Afghan leaders have pursued an irredentist line of nationalist diplomacy which led to the breaking of diplomatic relations in May, 1961. This was restored only after the signing of the Treaty of Tehran Accord of May 30, 1963. See Pakistan Yearbook for 1974.

Also see Fazul Haque Kazi, Law and Politics in Pakistan (Karachi: Royal Book Co.. 1976), Chapter 15.

${ }^{16}$ For some Pakistani views on this matter, see Foreign Minister Sharifud-Din Pirzada, "Foreign Policy of Pakistan," The Pakistan Times Annual, 1968, p. 37; Ahmad Ali Khan, op. cit.
}

${ }^{17}$ Sharifud-Din Pirzada, Op. cit., p. 37. 
Minister one can add what Ambassador Ispahani wrote in 1968. In his view, Pakistan's decision to join CENTO was a mistake in the sense that it trapped Pakistanis in a dangerous ideological web. To quote him directly, he said that the decision "tarnished our image among our own co-religionists and created such hatred and hysteria against the pact in general, and against the then government of Iraq in particular, that it resulted in the assassination of the Iraqi royal family and Prime Minister. ${ }^{18}$

\section{B. Pakistan and the Development of the Organization of Islamic Conference (OIC)}

The institutionalization of Islamic solidarity became a reality only when the universal political and diplomatic conditions made it possible. It was in 1969 when an arsonist burned the al-Aqsa Mosque in Jerusalem that the call for greater Muslim unity became an electric message that galvanized almost all Muslim states to action. With the benefit of hindsight we can now see how the whole idea developed in the Muslim world. It was indeed the painstaking efforts of the late King Faisal of Saudi Arabia that led to the successful convening of the first summit of Muslim Heads of State since the abolution of the Muslim Caliphate by Kemal Ataturk and his confederates in Turkey.

What was it that made King Faisal more successful than his predecessors in Pakistan and elsewhere in the Muslim World? Why was the idea embraced in 1969 and avoided in 1947-1955, when the Pakistani leaders were agitating for greater unity among Muslims? In this section of the paper we intend to identify the factors and forces which together helped create a climate of opinion favorable to Islamic solidarity in an institutionalized form.

In tracing the origins and history of the OIC, we must bear in mind that many Muslim intellectuals and leaders had put forth proposals as to how such an organization was to be structured. Such proposals were indeed their responses to what they perceived as evidence of Muslim weakness in world politics and diplomacy. It was also their way of creating the conditions for an Islamic resurgence in the twentieth century. Yet, all these earlier efforts, we must now conclude retrospectively, were still births or mental embryoes of the Muslim mind that never saw the light of day. During the interwar period the closest thing to an organizational manifestation of Islamic solidarity were the series of conferences organized by the Mufti of Jerusalem to mobilize Muslim opinion and support against the Zionist threat to Arabs in British mandated Palestine. After the Second World War the Pakistani drive was the big streak in the Muslim horizon. It triggered a series of

${ }^{18}$ M.A.H. Ispahani, Op. Cit., p. 17. 
moves between and within the Muslim states. Around this time President Sukarno of Indonesia also convened the Afro-Asian Islamic Conference to follow soon after the better known and more widely celebrated Bandung Conference. The conference, like the ones held in Pakistan, was a great jamboree for Muslims and it brought together peoples and their leaders who were previously cut off from each other by their former colonial rulers.

But even though Muslim leaders like Sukarno tried to create an organizational structure for the Afro-Asian Muslims, their attempts failed to institutionalize the idea because the forces at work in the international system at this time negated any idea of alliance based on religion. It is certainly true that Islam, as Ali A. Mazrui argues, is an Afro-Asian religion, but the fact that Arab, African and Asian leaders inherited colonial boundaries with several religions made territorial or demotic nationalism much safer politically than any ideology or sloganeering based on religion. In the case of the Arab world Arab nationalism was beginning to gain ground and Nasser's Philosophy of the Revolution, ${ }^{19}$ published soon after the Free Officers seized power from King Farouk, emphatically pointed to greater Egyptian identification with Pan-Arabism. Of course this feeling was beginning to gain ground among Egyptian political and intellectual leaders before the Second World War. Yet in noting this earlier form of Pan-Arabism in Egyptian society, one must hasten to add that Nasser was principally responsible for the elevation of the concept to a powerful international slogan and symbol for the Arabs. This Pan Arabist position of Nasser was certainly incompatible with the efforts of the first batch of Pakistani leaders in the 1947-54 period. The same focus on local nationalism was evident in Southest Asia where the Indonesians had their own dreams of becoming a political giant in that region. This spirit of nationalism, coupled with the fact that colonialism was still the order of the day in many AfroAsian colonies with Muslim majorities, made it virtually impossible for global Islamic solidarity to develop.

From the Pakistani angle, one could argue, the rise and development of the Organization of Islamic Conference (OIC) coincided with a number of events both within the domestic political system and the international arena. Domestically, the climate of opinion among the ruling elites in Pakistan became more disposed once again to diplomatic overtures to the Muslim World, because the elites who had earlier tied Pakistan to Western security alliances were themselves becoming very disillusioned with the result of their political investments in the West. Having put their eggs in foreign baskets and then found a few of them crushed because of Western reluctance to come to their aid in time of

${ }^{19}$ Gamal Abdul Nasser, The Philosophy of the Revolution (Buffalo, New York: Economic Books, 1959). 
need, the Pakistanis decided to diversify their diplomatic and political ties abroad. This new mood among Pakistan's leaders led to a series of diplomatic moves into the Communist world, an area that was until then the outer limits of Pakistan's diplomacy. One immediate result of this venture was the Soviet involvement in the South Asian search for peace between India and Pakistan and the negotiation of the Taskent Declaration, which one Pakistani observer described as "a boost to Soviet diplomacy in the eyes of the Afro-Asian World."20

Pakistan's domestic situation at this time, one can now argue, was going through a flux. The military rule of President Mohammad Ayub Khan was being challenged by various forces, and the call for civilian rule was getting louder and louder. It is against such a background that one can further argue that the rise of Zulfikar Ali Bhutto interestingly coincided with this new drift from military alliances with the West and the opening up to the Third World countries. Indeed Bhutto did much to change Third World attitudes and perceptions of Pakistan. His rise to power first as a protege or collaborator of General Khan and later as his own man, opened the door to closer cooperation with Third World countries and most especially, with the Communist countries. ${ }^{21}$ Because Bhutto wanted to widen the circle of Pakistan's friends he did not hesitate to travel far and wide to realize such an objective. He strongly identified with the Afro-Asian Movement and went to the extent of saying that "Afro-Asian solidarity is not a myth nor an abstract philosophy, but a condition necessary both for our individual advancement as well as our collective protection." 22 In retrospect, one can now argue that Bhutto's Pakistan was forced by domestic and international realities to adjust her foreign policies. Having joined the Commonwealth and saw how it abandoned Pakistan in her clash with India, and having trusted the U.S. only to learn that American aid and support did not and would not extend to a war with India, the Pakistani leaders gravitated towards the path of diplomatic internationalism, that is, greater contact with Third World nations, especially the Muslim lands, and greater dialogue with the Soviet and their allies. ${ }^{23}$

${ }^{20}$ See Pakistan Horizon, Vol. XIX, No. 1. 1st Quarterly, 1966, p. 6.

${ }^{21}$ Zulfikar Ali Bhutto. The Myth of Independence (London, Lahore, Karachi, Dacca, Pakistan: Oxford University Press, 1969), p. 114.

${ }^{22}$ For some discussion of Pakistan's membership in the Commonwealth, see K. Sarwar Hassan, Pakistan and the Commonwealth (Karachi, Pakistan: Pakistan Institute of International Affairs, January, 1950).

"Anwar Syed, "Sino-Pakistan-Relations-An Overview"; Pakistan Horizons, 2nd Quarterly, 1969, Vol. XXII, No.2, p. 107. Syed Identified the main areas of tensions in SinoPakistani relations. (1) Pakistan's inability, from 1953-61, to support China's (1st effort on Jan. 4, 1950) admission to UN. (2) Paksitan's alliance with the U.S. (3) Pakistan's occasional endorsement of the American two-China Policy. (p. 108)

ties. (p. 108)

Khalida Qureshi “Major Factors in Pakistan-East European Relations”, Vol. XXII, NO. 3, Third Quarterly 1969, pp. 238-248. 
Speaking retrospectively again, one can say that the change in Pakistan policy towards both the Afro-Asian World and the Muslim World was the result of the harrowing experiences of the 1965 war with India. During this military encounter the Pakistnai policy makers came to realize that, when the chips are down, only the Muslim countries would come to their support. As M. Ahmad notes, "The spontaneous support of Iran, Turkey, Indonesia and Saudi Arabia proved invaluable." ${ }^{24}$ Yet, as he correctly pointed out, no Muslim alliance would be strong enough to counteract the two global powers.

To President Bhutto, who became a major architect of the second Pakistani drive for global Islamic solidarity in international politics, ${ }^{25}$ the national interests could and must be served through international diplomacy. He identified the following areas as important sources of diplomatic support for Pakistan: (1) Muslim States; (2) normalization with three Global Powers (The U.S., the U.S.S.R. and China); (3) an understanding with India, a policy explored before his own tenure as Foreign Minister; (4) greater involvement with Afro-Asian countries; (5) establishment of ties with Francophone Africa and Muslim African states; and (6) overtures to Latin America. ${ }^{26}$

In addition to conditions in South Asia one must also take note of what was going on in West Asia in particular and the Third World in general. In West Asia, the evidence now clearly shows that the forces of PanArabism were in retreat. Nasser's army and air force were crushed and humiliated by Israel and Nasser himself, as Hassanein Heikel, Nasser's confidante, wrote in another context, was in the years after the June 1967 War a wounded lion. ${ }^{27}$ This lion of the Arabs was being gradually challenged and eclipsed by the Saudi monarch, King Faisal. After having fought Nasser over the question of who should rule North Yemen, the Saudi King made peace with his Egyptian rival. During the period of conflict with Egypt, King Faisal tried to raise the banner of Pan Islamism, but all his efforts at the time were thwarted by Nasser and his progagandists who charged that the "Islamic Front" was a Western creature and would serve Western interests. This Nasserite position won the battle before June, 1967. It however lost the war to the Pan Islamic forces in years after the defeat of Egypt. King Faisal's call for Pan

${ }^{24}$ Mustaq Ahmad, Pakistan's Foreign Policy (Karachi, Pakistan: Space Publishers, 1968). p. 143.

${ }^{25}$ According to Shahid Javed Burki, Bhutto used international Islamic symbolism to counter the leftist elements of his party led by Mubashir Hassan. He claimed that Bhutto used the Islamic Summit at Lahore, the center of leftist politics in Pakistan, to woo popular support. See his Pakistan Under Bhutto, 1971-1977 (New York: St. Martins, 1980), p. 179. ${ }^{26}$ Zulfikar Ali Bhutto, op. cit.; see also his Foreigm Policy of Pakistan, A Compendium of Speeches Made in the National Assembly of Pakistan 1962-64 (Karachi, Pakistan: Pakistan Institute of International Affairs, 1964).

${ }^{27}$ This characterization of Nasser was made in his Cairo Documents. 
Islamic solidarity became a reality in 1969 , following the burning of the al-Aqsa Mosque by an arsonist in Israel.

In discussing the formative years of the OIC, one must point out that Saudi Arabia, Morocco, Pakistan and Malaysia played an important role in bringing together the various factions of the Muslim World. Two problems which affected the fledgling organization was the delicate question of Indian representation and the participation of the Palestine Liberation Organization (PLO) in the deliberations of the organization. The first problem, which commanded the attention of the Pakistnai delegation, was the mistake of the conference organizers to allow the Indian Ambassador in Rabat, Morocco to participate in the Conference. This was a very ticklish question, but after much behind-the-scene Pakistani maneuverings the matter was resolved in favor of Pakistan. India was not acceptable as a member of the Islamic Conference. The other problem, which was the creation of the organizers again, became a hot issue in Kuala Lumpur when the Malaysian organizers of the next meeting of the OIC refused to seat the PLO on the ground that it is not a state and so could not be treated as such. Pakistan was involved in both issues. True, her immediate interest was tied to Indian presence and representation in the OIC, and she fought more fiercely on this issue than the latter. However she was one of the Muslim states to argue for the Palestine representation.

In concluding this section one can maintain that Pakistan's reinvolvement with Islamic solidarity at the global level was occasioned by both domestic and international changes. Pakistani leaders were disillusioned by their ten years of military entanglements with Westernsponsored organizations like CENTO and SEATO, and the rise of the Pan-Islamic movement in King Faisal's Arabia and beyond alerted them to stress and promote the areas of convergence between their country and other states in the global Islamic Ummah.

\section{Pakistan in the Organization of Islamic Conference (OIC)}

Pakistan's place and role in the OIC has been determined by her size and population. In 1969 when the OIC was formed in Morocco, Pakistan was the most populous. These two sources of power should have made her one of the leaders of the movement. However, the train of historical events created conditions in the 1970 s which gave greater financial clout to less populated and geographically smaller states in West Asia.

It is indeed against this background that one should examine the role and activities of Pakistan in the OIC. To Pakistani leaders, the OIC is another major international platform to project Pakistani interest and to cultivate friends and allies for future events. In the OIC the role played by individual members is diplomatic and political. In my view, Pakistan has been at the center of things in the Islamic Conference. This is evident in terms of number of conferences hosted and the role played in such 
meetings. ${ }^{28}$ It was for example at the Islamic Summit Conference of Lahore, Pakistan, on February 22-24, 1974 that flesh and blood was given to the idea of an International Islamic Bank. An economic committee was set up to discuss practical means for economic cooperation and help the poor members. ${ }^{29}$

Six months after Lahore a meeting of the Muslim Finance Ministers was held in Jeddah, Saudi Arabia on August 10-13, 1974. They discussed the draft agreement for the organization of the Islamic Development Bank (IDB) presented to them. The final draft was originally signed by the Ministers' of Finance of Guinea, Algeria, Bangladesh, the United Arab Emirates, Tchad, Egypt, Indonesia, Jordan, Kuwait, Lebanon, Mali, Saudi Arabia, Senegal, Sudan, Somalia, Tunisia, Turkey, North Yemen and Malaysia. Libya and Syria joined later.

Pakistan's involvement in the IDB was financially small in comparison to Saudi Arabia or other oil-producing states. The declared capital of the IDB was fixed at $\$ 2$ billion Islamic Dinars, a Dinar is equal to unit of the special Drawing Rights of the IMF, each unit being worth at the time $\$ 1.20$. According to IDB Principles, the bank should begin its operations once the 750 million Dinars were subscribed to by the membership. The participation of the member states was declared as follows:

Saudi Arabia 200 million, Islamic Dinars,

The United Arab Emirates 40 million, Kuwait 50 million

Egypt 25 million, Algeria 30 million

Pakistan and Indonesia 25 milion each,

Malaysia 16 million, Turkey, the Sudan, the Sultanate of Oman,

Morocco 5 million each, Jordan 4 million.

Ten other countries contributed a total of 25 million Dinars. These are Guinea, Tchad, Lebanon, North Yemen, Mali, Mauretania, Niger, Senegal, Somalia and Tunisia. Sometime after the ratification of IDB, Libya joined the agreement and pledged 45 million. Syria, whose application came much later bought 250 shares which is the minimum permitted under the agreement. Iraq was for a long time the odd-man out. ${ }^{30}$

Apart from being an active member of the OIC Pakistan has also benefitted from such an organization. On June 6, 1979 she received $\$ 6.19$ million for her Pakistan Industrial Credit and Investment Company. Under an agreement signed in Jeddah, she was supposed to carry out a study of projects for IDB equity participation in medium and small projects. By the end of 1979 , the Islamic Development Bank loaned $\$ 20$ million to Pakistan to finance her National Oil Refinery Company's

${ }^{2}$ The 2nd Islamic Foreign Ministers Conference was held in Karachi from Dec. 26-28, 1970. ${ }^{20}$ For details on this meeting, see Record of the Arab World, 1974, Vol. 1, p. 940.

${ }^{30}$ Saudi Arabia Yearbook. 1980-81, p. 95. 
purchase of crude oil from the Saudi Petromin. ${ }^{31}$ This loan to Pakistan brought the total of the IDB loans to Pakistan to $\$ 110$ million. During this five year period, the Bank had given out 136 loans with about $\$ 1,173$ million to 31 Muslim states. Total membership at this time had climbed to 36 and paid-up capital was $\$ 974.9$ million. The net profit for 1979 was $\$ 5.3$ million from its operations in member countries. Of these $7 \%$ were in agricultural projects and $52 \%$ in industry. ${ }^{32}$

\section{PAKISTAN AND POLITICAL ISSUES AT OIC MEETINGS}

When the Soviets moved into Afghanistan a wave of resentment swept through most of the Islamic World. The Saudis who were then very concerned about the trend in the Red Sea area and in the Northern Tier, began to call on the Carter administration to take action. But not to rely only on U.S. support the Saudis, in concert with Morocco and Pakistan, started lobbying for a conference. On January 7, 1980 Prince Saud Faisal announced a meeting of the Muslim states. On January 16, 1980 the Morocean Assistant Secretary-General of the OIC, Mr. Qasem alZuhairi, announced that 23 members of the 42 member organization have agreed to attend an emergency meeting of the OIC scheduled for Islamabad on January 26, $1980 .^{33}$

Contacts among Islamic countries were underway for taking measures against the Soviet intervention in Afghanistan. The Saudi Foreign Minister consulted with the Moroccan Foreign Minister who was in Riyad to deliver a letter to King Khaled from King Hassan II. Prince Faisal said that a Muslim strategy is being worked out through consultations with either countries.

What complicated matter for the $\mathrm{OIC}$ and the conservative Arab states and Pakistan was the activities and propaganda of the rejectionist Arab States who were in many cases closely linked to the Soviets and were therefore quite reluctant to attack the U.S.S.R. in the name of Pan Islamism. These states included Syria, the ring leader of such a diplomatic front, Libya, South Yemen, Algeria, and the P.L.O. Unlike their more conservative brethren, the leaders of these states saw Palestine as the more important issue. They were more bitter against Camp David than against Soviet intervention in Afghanistan. ${ }^{34}$ When the Islamabad conference took place however, only Syria, South Yemen and Afghanistan were absent. The PLO sent a delegation which served as observer.

President Mohammad Zia ul-Haq opened the conference and urged the Muslim World to send an "unequivocal message" to the Soviet Union,

\footnotetext{
sI Ibid., p. 96.

32Tbid., p. 97.

s3bid., p. 97.

${ }^{34}$ Ibid., p. 97.
} 
demanding the withdrawal of its troops from Afghanistan. After three days of deliberations the Muslim leaders issued a communique in which, according to a UPI correspondent, 36 Muslim States called for the immediate withdrawal of the Soviet Union. This communique echoed the words of many Muslims around the World. In the Pakistani religious Press, editorials after editorials attacked the Soviets for their intrusion into an Islamic country. The Rabetah al-Alam al Islami (The World Muslim League) launched a series of editorial attacks on the Soviet invasion of Afghanistan. On January 8, 1980 the Shyakhs at al-Azhar, whose country was suspended from the OIC, called for a conference of Muslim Heads of State to discuss ways of countering the Soviet "atheist", military intervention in Afghanistan. It also called for a similar meeting of all Islamic universities and organizations and asked Muslims to provide whatever aid to their Afghan brothers fighting Soviet aggression.

The Afghanistan issue has been a major preoccupation of Pakistan. At the Islamabad Conference Agha Shahi, Chairman of the conference, indicated in a concluding speech that the Soviet intervention in Afghanistan had prompted the Muslim world to edge away from Moscow. He reassured his guests that the Muslims wish to be independent of big power domination when he said: "we have proven in this conference that the Islamic World is an independent factor." As President Zia ul-Haq's foreign affairs adviser, Mr. Shahi stated Pakistani fears and apprehensions. After having gone through so many obstacles in their relations with nationalist Afghanistan, Pakistani leaders now wondered what the future augurs for them in communist dominated Afghanistan.

To protect herself and to draw from the emotional, political and diplomatic resources of sister Muslim states Pakistan $\mathrm{ma}_{\mathrm{a}}$ : ged to get a hearing for six Afghan leaders who stated their case before tr. nolitical committee of the conference. In addition to this appearance of th. $\&$ mujahideen, the final communique of the conference and the suspension of Afghanistan from the 42-member organization were defeats for the Soviets in their efforts to win legitimacy for the Afghan government of President Babrak Karmal. Infact the first 11-point resolution "condemns the Soviet military aggression of the Afghan people, denounces it and deplores it as a flagrant violation of international law." It urged the withdrawal of Soviet troops and demanded that they refrain from acts of oppression and tyranny against the Afghan people.

At this conference in Islamabad the Muslim states were also urged to withhold recognition of the Kabul government and to sever diplomatic ties. Nine Muslim countries declined to accept this arrangement. There was also a lack of consensus on the question of Muslim boycott of the Olympics. Eleven Muslim countries objected to the call on Muslim states 
to consider boycotting the Summer Olympics in Moscow. ${ }^{34}$ a

Pakistan was given another opportunity to host another major Islamic gathering in May 17-22, 1980. This time the Muslim Foreign Ministers were convened to discuss the issues raised earlier by their Heads of State. This 11th Session of the Islamic Foreign Ministers Conference was attended by representatives of 38 states and the P.L.O. excluding Egypt under Sadat. What was interesting at the May Conference was the Pakistani organizers allowed the Iranians to include in their delegation six representatives of the Afghan mujahideen groups, who were excluded from the January meeting.

At the end of this conference Mr. Agha Shahi of Pakistan read the final resolutions of the conference. The delegates denounced the presence of foreign bases in Islamic countries and warned them against granting military facilities or bases to foreign forces; called on the Islamic countries to sever their diplomatic and economic relations with any country which moves its embassy in Israel to Jerusalem or which recognizes Jerusalem as the capital of Israel; expressed its full support for the struggle of the Palestinian people under the leadership of the sole representative of the Palestinian people, for regaining its national rights and establishing its national independent state in Palestine; denounced the Camp David Accords and the Egyptian-Israeli Peace treaty and the normalization of relations between Egypt and Israel. The delegates also denounced the "unfriendly" conduct of the United States toward the Palestinian people. When viewed from a Pakistani perspective, one could say that resolutions such as these ones which support the Palestinians, echoed much of what has been constant in Pakistan's foreign policy.

In examining Pakistan's role in the OIC, one must also point out that sometimes Pakistan leaders have to balance their Muslim interest and their global interest. This was evident when Pakistan and Muslim African states expressed reservations on a resolution calling on OIC members to sever their ties with the United States of America. To the African states, such a decision was a matter that should be first discussed at the Organization of African Unity. ${ }^{34} \mathrm{~b}$

But, as indicated above, the Afghan issue has commanded Pakistan's attention more than any other since the early period of independence when the Kashmir issue dominated Pakistani consciousness. Because of the gravity of the situation and Pakistan's desire to maintain her sovereignty and security, the conference of Foreign Ministers formed a three-member committee to work for a withdrawal of Soviet forces from Afghanistan. This committee was authorized to take any initiative it

\footnotetext{
${ }_{34}{ }^{\mathrm{a}}$ lbid.

${ }_{34}{ }^{b}$ See Naveed Ahmad, "The Eleventh Islamic Foreign Ministers Conference, "Pakistan Horizon, Vol. 33, Nos. 1-2, 1st and 2nd Quarters, 1980. p. 67.
} 
considered necessary, including visits to the Soviet Union and Afghanistan. The spirit of the Muslim delegates was perhaps captured by the former Iranian Foreign Minister, Sadegh Ghotbzadeh, when he said: "We shall go to Moscow if invited (and) we are not going to beg the Soviet Union to negotiate with us." 35

Besides the Afghan problem which is now an international issue, there is the war between Iran and Iraq. Pakistan foreign policy in the early period, as we have seen in the first section of this paper, was geared towards collaboration with these neighbors. During the Shah era in Iran the situation was more predictable to the Pakistani leaders. There were many areas of convergence between Iran and Pakistan and their common cause was institutionalized in the form of the Regional Cooperation for Development (RCD).

When the Shah fell in 1979 and the reins of government passed to the Muslim revolutionaries the Pakistani leaders had to make the necessary adjustment. Relations continued to be healthy, although in certain Pakistani quarters anxiety and apprehension about Iran's policy and direction became predominant. These apprehensions were occasioned by domestic and foreign considerations. On the domestic front, the Paksitnai leadership was dealing with a populace whose imagination was fired by the lightening speed at which the "formidable Shah" crumbled under the telling blows of the Islamic revolutionaries. Added to this was the fact that the Iranian revolution raised the old issue about Pakistan's true identity, that is, how Islamic is Pakistan? Since Pakistan was the only Muslim state in this century that came into being for the Muslims and to be governed by the Muslims, one begins to wonder how the changes in Iran could affect Pakistanis. As Shaheen F. Dil reminds us, "(i)t was not until 1962 that the government of Pakistan made a conscious effort to emulate Islam." 36 The author attributes this state of affairs in the first fifteen years of Pakistan to "the ingrained sense of western-oriented secularism". ${ }^{37}$ Though some Pakistanis may take issue with Dil's interpretations of their country's association with Islam, the fact remains that the arrival of Imam Khomeini in Iran made it glaringly clear that an Islamic state is a possibility and secular Muslims must now either put up a fight if they wish to prevent a takeover from the Muslim revolutionaries or swim with the tide of Islamism in Darul Islam. In the case of Pakistan we can say that the rise of President Zia ulHaq predated by a year or two the coming to power of the Islamic revolutionaries in Iran. Judging from his record one could say that his regime decided to follow the trend which was discernible in the Muslim

\footnotetext{
${ }^{35}$ Quoted in Saudi Arabia Yearbook 1980/81. (Beirut: The Research Publishing House, 1982).

${ }^{36}$ See his "The Myth of Islamic Resurgence in South Asia". Current History. April, 1980.p. 147.

silbid., p. 147 .
} 
countries of West Asia. By 1980/81 the Iranian revolution was already on the way towards institutionalization. In the Arab East Saudi Arabia and other Gulf States, who had some forms of Islamic governments which emphasize more the legalistic elements of Sharia rule, were beginning to enforce more stringently what was heretofore considered Islamic laws and regulations based on the Sharia. Even Egypt under Sadat clamped down on some of the pleasures of the wine bibers and other backsliders of the Muslim community. In Libya President Muamar Qaddafi's Jamahiriya with some form of Islamism was being paraded in a number of generously sponsored conferences on the Green Book. In almost all these Arab Muslim countries, government-sponsored Dawah organizations came into being. The most active being Libya's Islamic Call Society (Dawatul Islamiyya), the Kuwaiti Council on Dawah and the Saudi Darul Ifta headed by Shaykh Ben Baz.

It is indeed against this background that one could better understand the role and activities of Pakistan under President Zia ul-Haq in the OIC. If one can argue that President Bhutto was the bridge-builder who refused to let Pakistan become marooned diplomatically because of earlier entanglements in alliances beyond her control and without much benefit, one could now argue that President Zia ulHaq has become one of the big boys of the Islamic bloc charged with the responsibility of organizing Muslim support for the recovery of Afghanistan. This new role for Pakistan has brought her closer to the conservative Arab monarchies in the Gulf and to the monarchy in Morocco. In fact, one can say that the Soviet Union's invasion of Afghanistan has been the most effective means of stating Pakistan's geopolitical and strategic interest to other Muslims, who until 1980 paid little or no attention to Pakistan's fears and suspicions.

President Zia ul-Haq's domestic policy of Islamization has been very much welcomed by the more conservative Muslim states in the OIC. What really impressed Muslim fundamentalists but ired Muslim secularists was inter alia the revival of the defunct Council of Islamic Ideology on September 1, 1977.38 This was attempted abortively by former President Bhutto on April 17, $1977 .{ }^{39}$ President Zia ul-Haq was praised by prominent ulema such as Maulana Mawdudi when he decided on December 2, 1978 to institute Shariat Benches and to abolish interest in a few government institutions. He was also lauded for his introduction of hadd punishments and the zakat-ushr ordinance of February 10, 1979.40

In concluding this section one can say that Pakistan's role in the OIC has changed her international posture. Whereas in the early 1950 s she

${ }^{38}$ Pakistan Times, 14, 20, and 24 November 1977, p. 1.

${ }^{39}$ Pakistan Times, December 4. 1978, p. 1.

40Pakistan Times, March 7, 1979, p. 8. 
was isolated in her call for Pan Islamism, in the late 1970s and early 1980 s she finds herself in the mainstream of such a movement. In fact, it is quite possible that Pakistan would provide the next Secretary-General of the OIC. This of course depends on her relations with other Muslim states, most specially the Gulf states who contribute more than their sister states to the coffers of this young organization.

But in pointing out the factors at work in the diplomatic and political shaping of OIC activities, one must also stress that such conferences do confer legitimacy. For example, President Zia ul-Haq's stocks must certainly have climbed up very high in Pakistan and beyond in the months before and after the successful conclusion of the 11th Annual meeting of the Islamic Foreign Ministers Conference. This was evident from the fact that the plenary session of the conference unanimously decided to request President Zia to address the 35th Session of the United Nations General Assembly on behalf of the OIC. As one Pakistani commentator observes, this decision "amply showed the trust that the Islamic world feels for Pakistan, as a promoter of Islamic solidarity and a defender of the cause of Islam." ${ }_{41}$ Of course, the sceptics, and detractors of President Zia would contend that his selection to speak for the Muslim world at the 35th Session of the UN General Assembly was a formality that is now widely accepted as a diplomatic way of rewarding the host for his country's hospitality and cordiality after a trying conference of a regional or global organization.

\section{Pakistan's Trade and Financial Relations With the OIC Member States}

One of the main objectives of the Muslim world today is to regain its old cohesion and links. To do this its peoples must rebuild the structures of commerce and trade that were torn down during the colonial era. Lamenting on the need for unity and pointing to some of the external factors which contributed to the present lack of meaningful trade and commerce between the Muslim states, Kemal Faruki writes:-

Matters are not helped by the fact that during the last two centuries, many Muslim regions came under the direct and indirect control of a colonial power who severed internal Muslim land communications, broke their inter-Muslim patterns of trade and diverted the cultural moorings of Muslim educated classes so that there is now a sense of isolation between even neighboring Muslim regions. ${ }^{42}$

\footnotetext{
${ }^{4}$ Naveed Ahmad Op. cit., p. 75.

${ }^{42}$ Kemal Faruki, "Approaches to Muslim Unity," Pakistan Horizon, Vol. XXV, No. 1, 1st Quarter, 1972, pp. 3-4.
} 
It was indeed against this background that the idea of Pakistan developed under colonial rule in British India. It was also the set of odds and circumstances that the leaders of Pakistan faced upon attaining independence from Britain. To deal with such realities the Pakistanis, who did not inherit much of the industries that British colonialism left behind in the post colonial sub-continent, had to build from scratch. While she was in the process of building her industrial base in the forties and fifties, Pakistan did not need an export market for finished products. However, to break away from the trade control of India, Pakistani leaders began to seek outlets in Asia and beyond. Counting on Islamic solidarity the Pakistani government started to venture into the markets of Darul Islam through the dispatch of trade missions, participation in trade fairs and through the attachment of commercial attache to embassies located in areas of great commercial potentials.

It was on account of these considerations that Pakistan signed a number of commercial and trade agreements with Muslim countries. To encourage Pakistani businessmen the government of Pakistan introduced in 1959 what was called the Export Bonus Scheme. This was designed to promote and encourage export. In 1961/62 bonus-earning items produced foreign exchange to the tune of 721.6 million Rupeesagainst 694 million Rupees in 1960/61.

Another scheme introduced in March, 1962 and designed to promote export trade of Pakistan by undertaking such financial risks of the exports that are not covered by normal insurance was the Export Credit Guarantee. In 1963 the Export Promotion Bureau of Pakistan signed trade agreement with Indonesia which expired in June 30, 1961. This was renewed for another year in 1961/62 with the understanding that its continuous operation depends on renewal. With such an understanding Pakistan went out to other parts of the Muslim world in search of markets. She signed a trade agreement with Morocco which granted her the most favorite trading partner. The main items of export from Pakistan in 1962 included jute, cotton, textiles, woolen textiles, surgical instruments, sports goods, cycle tubes and tyres and accessories, machinery and sanitary equipments. This agreement which was originally signed on April 20, 1962 was renewable and it served as the basis for inter-Muslim trade before the emergence of the OIC.

Trade agreements were also worked out with Iraq whose import list from Pakistan included jute, jute manufactures, cotton piece goods, cotton yarns and thread, tyres, tubes and rubber products, rice, electric goods, tea, surgical instruments, and board and paper. Pakistan's import from Iraq has consisted of dates, cement, petroleum and petroleum products, including asphalt.

Besides the above-mentioned states, Pakistan also sent trade delegations to Lebanon, Jordan, Saudi Arabia, Somalia, Sudan, and U.A.R. to introduce her manufactures and to develop business in these 
regions..$^{43}$ As pointed out in the first section of this paper, the Pakistani drive in the 1950s was met with failure. In the 1960s, however, things were a little bit better. In 1975 Pakistan signed a most favored nation trade agreement with Mauretania. ${ }^{44}$ All these efforts were designed to find markets for Pakistan and to bring her closer to other Muslim sister states. This was most evident in her relations with Iran and Turkey under the umbrella of the Regional Cooperation for Development (RCD). Through this structure these three Muslim states hoped to promote an Islamic subregional industrial cooperation. Although the RCD has not functioned as expected, the fact remains that those who organized the $\mathrm{OIC}$ and its various organs and bodies for Muslim trade and industrial cooperation have looked at past errors and past successes in the Muslim world.

In Table 1, we provide some statistical data on Pakistan's trade with the Muslim world in 1976, when the OIC was just beginning to get institutionalized. The figures in our table show that the bulk of Pakistan's trade is primarily with the western countries, although some inroads were being made in the Middle East. The data also reveal that in 1974/76, among all the Muslim trading partners of Pakistan, it was only with Saudi Arabia and Kuwait that she had a negative balance of trade. This of course was due to the oil price increases and Pakistan was suffering the same fate as the other Third World countries. What obtained at this time

Table 1

DIRECTION OF FOREIGN TRADE

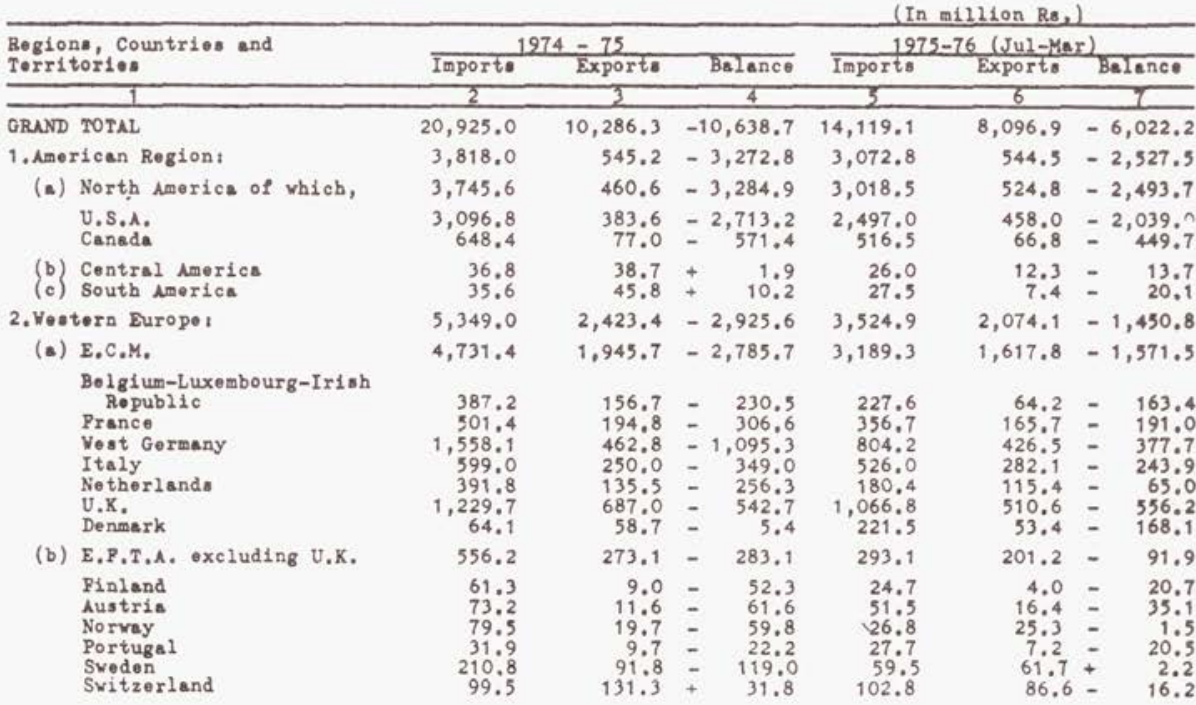

43Pakistan Government, Pakistan, 1961-62 (Karachi: Pakistan Publication 1963).

${ }^{44}$ See Pakistan Yearbook, 1977, p. 328. 
Table 1 (continued)

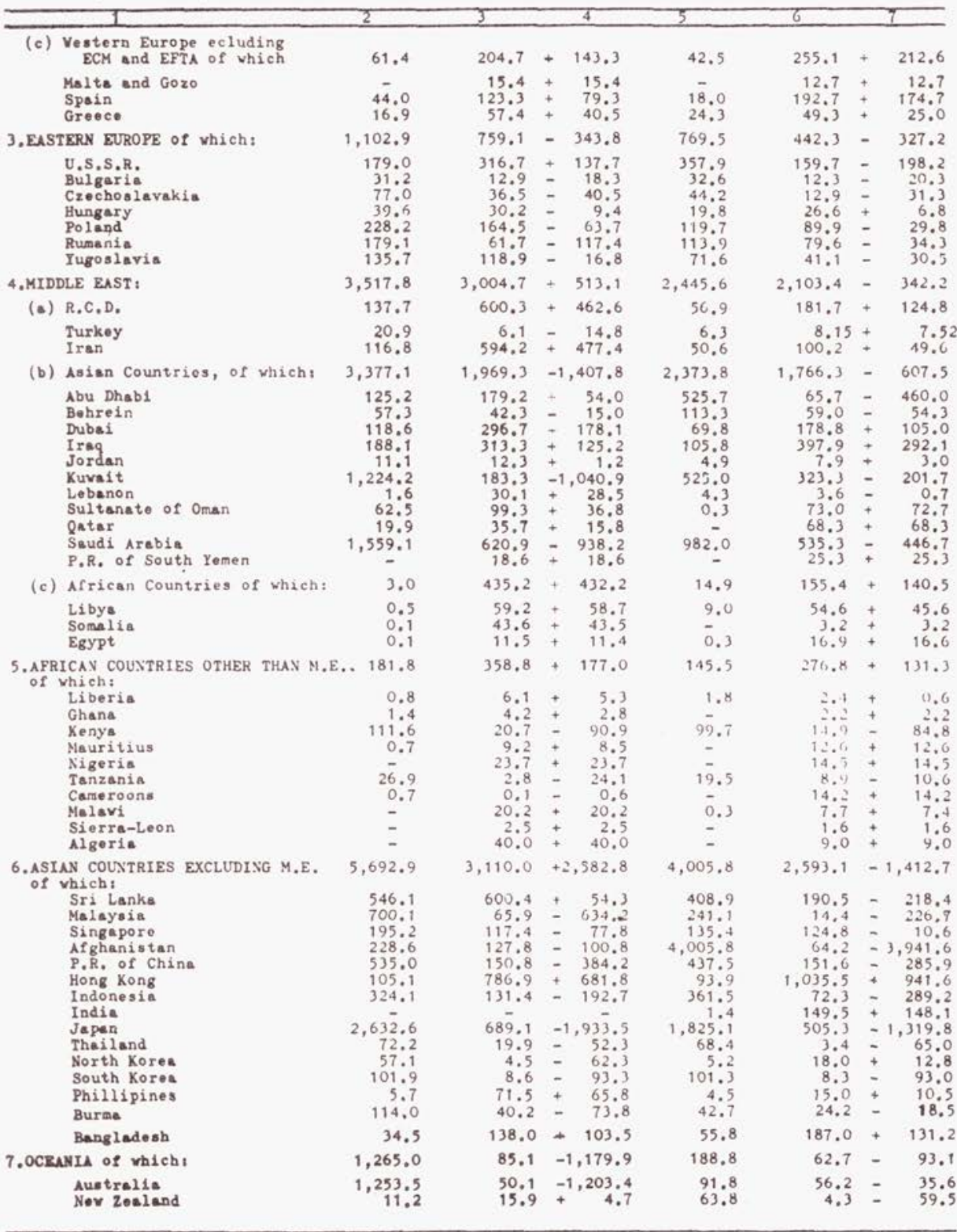

SOURCE: Pakistan Year Book, 1976

was certainly a change from the early 1970 s when she had a favorable trade balance. ${ }^{45}$

${ }^{45}$ See Pakistan Yearbook, 1977, p. 313. 
In Table 2, we find that in the 1980s, Pakistan's trade pattern seems to have shifted very slightly towards the Muslim countries. But the figures still show that trade with Middle East and Southeast Asian Muslim countries now constitute over a quarter of her imports and almost twenty per cent of her exports.

TABLE 2

DIRECTION OF FOREIGN TRADE

(Million Rupees)

\begin{tabular}{|c|c|c|c|c|c|}
\hline \multirow{2}{*}{ Regions'Countrics } & \multicolumn{2}{|c|}{$1979-80$} & \multicolumn{2}{|c|}{$1980-81$} & \multirow{2}{*}{$\frac{1981-82 \mathrm{Jul}-\mathrm{Mar}}{\text { Imports Exports }}$} \\
\hline & Imports & Exports & Imporis & Exports & \\
\hline 1 & 2 & 3 & 4 & 5 & 7 \\
\hline
\end{tabular}

Grand Total:

1. American Region
(a) North America Of which:
U.S.A. ...
Canada ...
(b) Central America
(c) South America

2. Western Europe

(a) F.C.M.

Belgium-Luxembourg
Irish Republic

Irish Republic $\quad .$.
France

West Germany

Italy

Netherlands

U.K.

Denmark

(b) E.F.T.A. Excl. U.K Of which:

Finland

Austria

Norway

Portugal

Sweden

$\begin{array}{lll} & \text { Switzerland } \ldots & 431.3 \\ \text { (c) Western Europe excl. } & 206.4\end{array}$

E.C.M. \& E.F.T.A. Of which:

Malta \& Gooz ... 0.3

$\begin{array}{llll}\text { Spain } \quad \ldots & \ldots & 141.1\end{array}$

3. Eastern Europe

of which:

U.S.S.R.

Bulgaria

Czechoslovakia

Hungary

Poland

Romania

Yugoslavia

4. Middle East
(a) R.C.D.
Turkey (b) Asian Countries
Of which:

... $46,929.123,410.153,543.729,279.5 \quad 38,503.6 \quad 17,563.3$

$\begin{array}{lllllll}\ldots & 6.755 .6 & 1,881.5 & 7,563.5 & 2.523 .3 & 4,729.8 & 1,677.4\end{array}$

$\begin{array}{lllllll}\ldots & 6,044.7 & 1,339.1 & 6,469.9 & 1,907.4 & 4,409.1 & 1,535.0\end{array}$

$\begin{array}{llllll}\ldots & 5,219.3 & 1,201.1 & 5,850.8 & 1,769.6 & 3,7\end{array}$

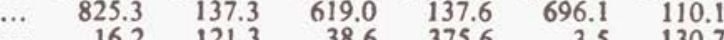

$\begin{array}{lrrrrrr}\cdots & 694.7 & 421.1 & 1,055.0 & 240.3 & 317.2 & 11.7\end{array}$

$\begin{array}{llllllll}\text {.. } 12.551 .5 & 5,905.8 & 12.738 .0 & 5,489.2 & 8,989.6 & 3,831.2\end{array}$

$\begin{array}{lllllll}\ldots & 11,266.8 & 4,884.4 & 11,091.0 & 4,536.7 & 7,654.7 & 3,163.3\end{array}$

$\begin{array}{lllllll}6 & 615.3 & 337.5 & 592.1 & 250.1 & 450.7 & 104.2\end{array}$

$\begin{array}{rrrrrr}2.148 .9 & 581.2 & 1.509 .2 & 623.3 & 60 \times .7 & 451.2\end{array}$

$\begin{array}{lllllll}\text {.. } & 2,308.7 & 1,429.6 & 2,694.0 & 1,260.2 & 2,391.8 & 747.8\end{array}$

$\begin{array}{lllllll}\ldots & 1,853.7 & 881.8 & 1,590.3 & 750.1 & 1,015.2 & 595.2\end{array}$

$\begin{array}{lllllll}\ldots & 1,093.5 & 376.2 & 1,040.9 & 375.2 & 749.4 & 214.6\end{array}$

$\begin{array}{lllllll}\ldots & 2,878.0 & 1,127.9 & 3,296.7 & 1,163.2 & 2,354.8 & 885.4\end{array}$

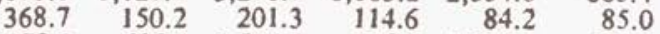

$\begin{array}{lllllll}\text { K. } & 1,078.3 & 695.4 & 1,204.1 & 719.6 & 1,010.4 & 495.6\end{array}$

$\begin{array}{lllllll}\ldots & 56.8 & 14.1 & 18.7 & 22.2 & 10.5 & 20.3\end{array}$

$\begin{array}{lllllll}\text {.. } & 121.8 & 46.1 & 105.3 & 61.6 & 119.1 & 33.8\end{array}$

$134.0 \quad 37.7-207.1$

$\begin{array}{lllll}37.7 & 207.1 & 44.8 & 87.5 & 24.7\end{array}$

$\begin{array}{lllll}24.6 & 31.1 & 34.0 & 26.7 & 11.7\end{array}$

$\begin{array}{lllll}162.1 & 332.0 & 158.7 & 297.8 & 150.1\end{array}$

$\begin{array}{lllll}410.8 & 509.9 & 398.3 & 468.7 & 254.0\end{array}$

$\begin{array}{lllll}326.0 & 442.9 & 233.0 & 324.5 & 172.3\end{array}$

$\begin{array}{lllll}16.9 & 0.1 & 13.9 & 0.1 & 1.3\end{array}$

$\begin{array}{lllll}230.8 & 307.2 & 157.6 & 293.6 & 150.4\end{array}$

$\begin{array}{lrrrr}77.0 & 51.2 & 60.0 & 26.8 & 19.7\end{array}$

$\begin{array}{lllllll}\ldots & 1,620.3 & 994.0 & 1,970.7 & 1,207.4 & 1,456.1 & 827.0\end{array}$

$\begin{array}{lllllll}\cdots & 511.6 & 524.1 & 456.1 & 447.7 & 213.5 & 360.7\end{array}$

$\begin{array}{lllllll}\cdots & 111.8 & 17.9 & 237.0 & 135.4 & 300.5 & 111.6\end{array}$

$\begin{array}{lllllll}\ldots & 135.6 & 60.9 & 151.6 & 107.8 & 105.8 & 108.5\end{array}$

$\begin{array}{lllllll}\ldots & 106.9 & 93.5 & 236.0 & 345.1 & 91.0 & 153.0\end{array}$

$\begin{array}{lllllll}\ldots & 170.9 & 129.4 & 345.8 & 39.4 & 152.3 & 10.5\end{array}$

$\begin{array}{lllllll}\ldots & 318.4 & 82.1 & 280.7 & 55.8 & 336.9 & 65.0\end{array}$

$\begin{array}{lllllll}\ldots & 223.1 & 74.1 & 230.5 & 56.1 & 243.8 & 13.9\end{array}$

$\begin{array}{lllllll}\ldots & 12,017.8 & 5,934.1 & 16,205.7 & 7,841.3 & 11,003.1 & 5,362.0\end{array}$

$\begin{array}{lllllll}\ldots & 163.1 & 1,166.8 & 60.5 & 2,537.7 & 253.3 & 588.8\end{array}$

$\begin{array}{lllllll}\ldots & 68.0 & 127.7 & 35.1 & 243.2 & 232.0 & 57.7\end{array}$

$\begin{array}{lrrrrrr}\ldots & 95.2 & 1,309.1 & 25.3 & 2,294.5 & 21.3 & 531.1\end{array}$

$\begin{array}{lllllll}\text {... } 11,842.9 & 4,413.8 & 16,134.6 & 4.909 .5 & 10,734.5 & 4.451 .6\end{array}$ 
Table 2 (continued)

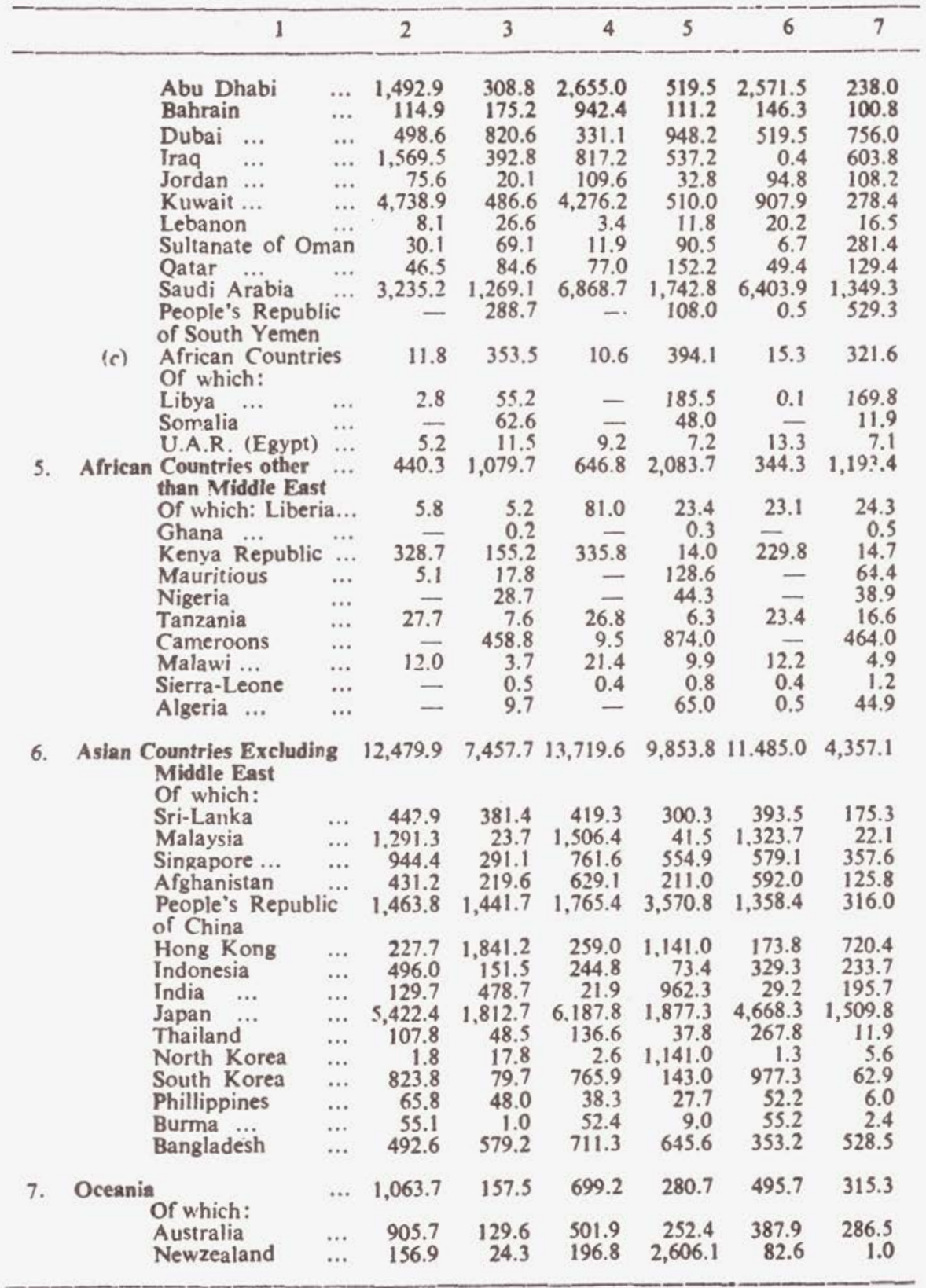

Source: Federal Bureau of Statistics 


\section{CONCLUSIONS}

In the preceding sections of this study the role and contributions of Pakistan to Islamic solidarity received our attention. We found that Pakistan's foreign policy went through three phases. During the first phase her leaders tried to steer a fairly neutralist position while simultaneously pursuing some form of Islamic universal solidarity with other Muslim states. This policy, according to the evidence gathered in this study, was short-lived and abandoned because of a number of factors. Chief among these were the rebuff from the Muslim states of West Asia and the growing feeling of insecurity among the successors to the Muslim League leadership.

The second phase was the period of close and intimate alliance with the United States. During this period the Pakistanis put their highly valued eggs in the American basket. This decision of the Pakistani leadership created the image of their country as the most allied of the allies of the U.S. in Asia. This period was characterized by massive U.S. aid and greater Pakistani dependence on American political and diplomatic direction.

The second phase passed away in the $1960 \mathrm{~s}$, when the Americans began to flirt militarily with India and to demonstrate to the Pakistanis that American interest in Pakistan was primarily to contain the communist menace. During the third phase the Pakistanis began to distance themselves from the Americans and to open up to the other super powers. They also began to pay their "overdue subscriptions" for membership in the Third World Movement. This was largely accomplished by Bhutto as Deputy Prime Minister and Foreign Minister and also as President of Pakistan.

In drawing up our conclusions of this study we can argue that Pakistan's role in the OIC has been a good barometer of her general performance in the wider Third World Movement. It is in the OIC where her Third World credentials have been subjected to less radical suspicious scrutiny; it is also in the OIC where she sits comfortably knowing fully well that India is not seated across the table threatening and challenging her claim for leadership and prominence.

Looking at the evidence available in this paper we could also argue that the OIC has provided a useful framework for meaningful economic and industrial cooperation between the independent Muslim states of the world. But in saying this, one must hasten to add that at the moment the weakest link in the Islamic chain of solidarity is economic cooperation. No Muslim state has yet reached what some economists now call the take-off stage of industrial and economic development. But, even if this is to be the case for sometime, the fact remains that the perennial dream of most Muslim states is to develop rapidly. Yet, to develop rapidly is to be able to live under stable political systems. This is the challenge of the Muslim world and in response to such a challenge, it seems, the Muslim 
leaders have decided to use the OIC as a plough that can help cultivate the vast fields of Muslim opportunities.

Another conclusion is that the OIC is now a reality in international politics and Muslim states would surely try their very best to keep it going in a world of turmoil and ideological disputes. Related to the above is the fact that the OIC, as Inis Claude, Jr., said in another context about the U.N., is a political tool. It has no permanent purpose other than the promotion of unity and solidarity among Muslim states. As a tool it can be effectively used by the Muslims if they continue to stick together whenever confronted by an external force.

Finally, one could conclude that Pakistan is an asset to the OIC. Her population and geographical size even after the breakaway of Bangladesh, together give her an important place in the OIC. She provided experts and official staff members at OIC headquarters and has participated effectively in many of the OIC organs and bodies. Up until recently Pakistan had one of her nationals serving as the Assistant Secretary-General of OIC. This writer had the opportunity to work with him while representing the Republic of The Gambia at the Islamic Solidarity Fund in the mid 1970s. In retrospect one could now say that Dr. Zafrul Islam of Pakistan and his colleagues, including Dr. Amadou Karim Gueye, the Senegalese Secretary-General of OIC, were actually those who began the process of transformation of the organization from a skeletal structure into what it is today.

Last but not least, we can say that the OIC's presence is widely felt in almost all councils of world affairs. Her diverse membership has made it possible for her to participate in almost all world diplomatic forums. To this end, she now enjoys observer status to many meetings of international bodies. This is indeed a major achievement for the Muslim world and one can now say that there is at least a framework for collaboration. The future of the OIC, one could argue, is linked to the future of all Muslim states; but in the very planning of the future of the OIC one must take into account the populous and the strategic Muslim states. Pakistan fits the first criterion by virtue of demographics and the second by virtue of geographic accident of history. Even if in the calculations of the super powers and the individual Muslim states Pakistan's demographic size is under played the fact remains that she is a strong force in the OIC and is likely to play a major role in the future. 